\title{
The Impact of Money Market Dynamics on the Economic Growth of Nigeria
}

\author{
Oluwaseun Okikiola \\ Principal Consultant, Axion Research, P.O. Box 2046, Lagos, Nigeria
}

\begin{abstract}
The notion that monetary policy is a panacea for economic growth remains empirically subjected to open research. This study tries to close up the knowledge gap by examining the impact of monetary policy on economic growth in Nigeria for the period 2010 to 2019. This study examined the impact of the monetary policy, influence of dynamics in the money market as well as the influence of deposit and lending activities of the money market on the growth of the Nigerian economy. Preliminary analysis shows evidence of long run equilibrium relationship which implies that the variables exhibit a common deterministic trend. By the regression estimates, Monetary Policy (MPR) has a significant and positive impact on Economic Growth $(b=0.021, t=3.86, p<0.05)$, Government Lending Activities has a significant and negative influence on Economic Growth $(b=-0.045, t=-2.52, p<0.05)$, and deposit activities (SADR) has a significant and positive impact on Economic Growth $(b=0.038, t=3.463, p<0.05)$. While lending rate has a significant and negative influence on Economic Growth $(b=$ $0.020, t=-1.986, p<0.05)$, the inverse relationship between lending rates and lending activity (with lower lending rate leading to higher lending activities, and vice-versa), a positive relationship exists between lending activities and economic growth. The results of the impact of monetary policy on economic growth in Nigeria depicts the nature of the financial structure, characterized by a low level of development. Monetary policy and deposit activities impact the economy positively. Therefore, the study recommends that measures to further promote monetary policy and deposits activities be put in place to promote economic growth. Policies at stimulating market forces to the right direction be considered.
\end{abstract}

Key words: Monetary Policy, Economic Growth, Long-run relationship, Regression, Money Market

\section{INTRODUCTION}

\section{Research Background}

$\mathrm{T}$ The growth of the economy of a nation constitutes one of the paramount aspirations of its stakeholders, particularly the government, investors, institutions, policy makers, and the population at large, to mention a few. The reason for this is not farfetched. The prosperity of the economy of a nation reduces the level of poverty and improves the quality of life of its citizens. According to Firebaugh \& Beck (1994), the growth of an economy serves as a means to an end, which is the betterment of the life of its people. Economic growth is sequel to the interaction and dynamics of several variables. Some of these variables include the capital formation, Foreign Direct Investment, employment, inflation, export and import, technological development, political factors, to mention a few.
However, critical to the dynamics, interaction, and direction of these variables within an economy is the financial market. This is hinged on the fact that the financial market facilitates investment by companies, individuals, as well as the government, which stimulates the dynamics, interaction, and direction of these variables in a way that results in economic growth.

The financial market, which is considered to be a market for the exchange of financial instruments or assets, stimulates the growth of an economy by promoting the efficiency in the flow of savings and investments within an economy, in such a way that aids the production of services and goods, as well as the formation and accumulation of capital (Darškuvienè, 2010;

Odunga \& Ayoyi, 2016; Haruna, 2019). While financial institutions and economic agents are considered to be key players within the financial market, research has shown that larger and more developed financial market players with higher trading volumes tend to generate more liquidity, which translates to more capital formation and accumulation, production of goods and services, consumption, and economic growth (Adambekova \& Andekina, 2013; Odunga \& Ayoyi, 2016). Assessing the financial market necessitates the decomposition of the market based on the types of instruments traded, and the duration of the financing offered by the instruments. Table 1 presents a summary of the research findings on these components of the financial market, their definition, as well as the assets traded in these markets.

\begin{tabular}{|c|c|c|c|}
\hline Author & Component & Definition & Assets trade \\
\hline $\begin{array}{l}\text { Adam } \\
(2009)\end{array}$ & Money Market & $\begin{array}{l}\text { A mechanism that } \\
\text { facilitates the lending } \\
\text { and borrowing of short } \\
\text { term funds }\end{array}$ & $\begin{array}{l}\text { Commercial } \\
\text { paper, } \\
\text { Treasury Bills, } \\
\text { Certificate of } \\
\text { Deposit }\end{array}$ \\
\hline $\begin{array}{l}\text { Adam } \\
(2009), \\
\text { Kizito } \\
(2012)\end{array}$ & Capital Market & $\begin{array}{c}\text { A market that } \\
\text { facilitates the supply of } \\
\text { fixed working capital } \\
\text { to the industry, as well } \\
\text { as medium to long term } \\
\text { financing for } \\
\text { government } \\
\text { expenditure. Comprises } \\
\text { of Bond and Stock } \\
\text { Markets }\end{array}$ & $\begin{array}{l}\text { Bonds, } \\
\text { Equities, } \\
\text { Derivatives, } \\
\text { Preference } \\
\text { Shares, } \\
\text { Debentures, } \\
\text { Government } \\
\text { Securities }\end{array}$ \\
\hline $\begin{array}{l}\text { Kizito } \\
(2012)\end{array}$ & Futures Market & $\begin{array}{l}\text { A market in which the } \\
\text { current price of a } \\
\text { commodity transaction } \\
\text { designated for a future } \\
\text { date is determined. }\end{array}$ & $\begin{array}{l}\text { Forward } \\
\text { Contracts }\end{array}$ \\
\hline
\end{tabular}




\begin{tabular}{|c|c|c|c|}
\hline $\begin{array}{c}\text { Kizito } \\
(2012)\end{array}$ & $\begin{array}{c}\text { Commodity } \\
\text { Market }\end{array}$ & $\begin{array}{c}\text { A market in which } \\
\text { commodities are traded } \\
\text { or exchanges }\end{array}$ & Commodities \\
\hline $\begin{array}{c}\text { Kizito } \\
(2012)\end{array}$ & $\begin{array}{c}\text { Insurance } \\
\text { Market }\end{array}$ & $\begin{array}{c}\text { A mhich } \\
\text { facilitates the buying } \\
\text { and selling of insurance } \\
\text { in a bid to redistribute } \\
\text { various risks }\end{array}$ & Insurance \\
\hline $\begin{array}{c}\text { Violeta } \\
(2010),\end{array}$ & $\begin{array}{c}\text { Foreign } \\
\text { Kizito } \\
(2012)\end{array}$ & $\begin{array}{c}\text { A market in which one } \\
\text { pair of currencies are } \\
\text { traded against another } \\
\text { pair of currencies }\end{array}$ & Currencies \\
\hline
\end{tabular}

While the components of the financial market identified and defined by various authors (as reflected in Table 1) show the diverse nature of the financial market, it is worthy of note that only two components of the financial market fulfil the financial market role that researchers such as Hartmann et al (2007) and Mihajlovic (2016) argue to be the transmission of funds from surplus to deficit areas of an economy, for the stimulation of economic activities and growth. These are the money market and the capital market. While other components of the financial market tend to focus more on trading of instruments or assets, the money market facilitates the transmission of short term funding, and the capital market facilitates the transmission of long term funding.

\section{Research Context and Justification}

Having highlighted the important role that the money and capital market play, this paper focuses on the money market. The focus on the money market is hinged on the assertions of Cœuré (2012) who argued that the money market plays three distinctive roles compared to other components of the financial market. These roles are the facilitation of the market efficiency and discipline, the stabilization of financing conditions within an economy, as well as the initial contact point in the monetary policy transmission. The focus on the money market is within the Nigerian context. Over the past two decades, Nigeria has witnessed a decline in the economic growth rate. Findings from the World Bank data base reflect a decline in the economic growth, measured by GDP growth, from $15.33 \%$ in 2002 to $2.21 \%$ in 2019 (World Bank, 2021). Given the critical role and the influence that the money market plays in the growth of the economy, as iterated by Cœure (2012), it is essential to assess the money market indicators and their dynamics, in a bid to understand the roles and influence that the money market and its dynamics has on growth of the Nigeria economy, from an empirical perspective; hence, the relevance of this research.

\section{Research Questions and Hypothesis}

In achieving the aim of this research, which is to empirically assess the impact that the money market dynamics has on the economic growth of Nigeria, the following are the questions that this research will seek to provide answers to;

1. What is the impact of the monetary policy of Nigeria on the output level of the economy?

2. How does Government lending activities influence the growth of the Nigerian economy?
3. What influence does the deposit and lending activities of the money market have on the growth of the Nigerian economy?

The following are the hypothesis that this study seeks to test;

Ho: : The monetary policy of Nigeria has no impact on the output level of the economy.

$\mathbf{H o}_{2}$ : Government lending activities have no influence on the growth of the Nigerian economy

Ho3: Deposit and lending activities within the money market do not affect the growth of the Nigerian economy

The current study is structured in 5 sections. Having discussed the introduction in section 1 , section 2 reviews existing literature as it relates to the concept, theories, and empirical studies related to this research. The methodology is discussed in section 3 . The results of the data analysis are presented in section 4, while the conclusion and recommendations are documented in section 5 .

\section{LITERATURE REVIEW}

\section{Conceptual Review}

The money market can be referred to as a market in which short-term financing and monetary services are offered. This definition of the money market draws from the research carried out by Goodfriend (2011), who highlighted the fact that the evolution of the money market is traceable to and sustained by depository financial institutions. Similarly, Adam (2009) defines the money market as a mechanism that facilitates the lending and borrowing of short term funds. Prajapati (2014) defines it as the part of the financial market where the borrowing and the lending of short-term funds takes place. While these definitions provide insight into how the money market works, with depository financial institutions playing a fundamental driver role in the market, they provide limited insight into the role and relevance of the market. A more elaborate definition of the money market was provided by Nwankwo (2001), who defines the money market as a market for the exchange of short-term financial instruments, which aid the development of a modern economy via the facilitation of trading and production activities. The relevance of the money market can also be seen in the capital market, as the stability and health of the money market is crucial to the development and efficiency of the capital market. The money market serves as the foundation for a market-driven system of intermediation that is efficient and competitive. The money market instruments include treasury bills, commercial papers, banker's acceptance, and certificates of deposits (Adam, 2009; Okoyan \& Peter, 2021). While treasury bills are short-term money market instruments that the government uses to raise short-term funding for its deficit or projects, commercial papers are short-term money market instruments that companies use in raising funds to finance their inventory or meet account payable obligations in the short term (Okoyan \& Peter, 2021). While a banker's acceptance is an instrument 
that promises future payment by a bank, a Certificate of Deposit is a certificate issued by a bank to a depositor of timed funds at a specified interest rate (Okoyan \& Peter, 2021).

While market dynamics, according to Banton (2021), can be referred to as the forces that impact on the price as well as the behavior of consumers and producers within a market, money market dynamics can be referred to as the forces that impact on the borrowing and lending activities of short-term funds, as well as the demand and supply of money market instruments. While these forces that drive the money market dynamics may cut across demand side factors and supply side factors, the dynamics in the money market are best captured and measured using money market indicators. According to the Central Bank of Nigeria $(\mathrm{CBN})$, these market indicators comprise of the Monetary Policy Rate (MPR), the treasury bills rate, the inter-bank call rate, as well as other short-term deposit rates and lending rates (Oni et al., 2012). A time series analysis of these money market indicators offer insight into the dynamics of the money market over a period of time.

Among the impact points of the money market dynamics is the growth of the economy. Ivic (2015) defines economic growth as the changes in the material production within an economy, during a short period of time, which often tends to be one (1) year. Cornwall (2018) defines economic growth as the process via which a nation's wealth increases over a period of time. According to Paul Romer, the growth of an economy occurs when its people engage in the rearrangement of it resources to make them more valuable (Econlib, 2019). Therefore, within the context of the assertion by Paul Romer, this study can be said to be focused on assessing how the trend in the money market indicators (which reflect the dynamics in the money market) have impacted on the creation of value via the re-arrangement of resources by the residents of Nigeria. With respect to the measurement of economic growth, the Council of Economic Advisers (CEA) under the Obama Administration are of opinion that the change in Gross Domestic Product (GDP) and the Gross Domestic Income (GDI) over a period are the common measures of economic growth. The GDP is the summation of the consumption expenditure, the investment expenditure, the government expenditure, and the net export within an economy, over a period of time.

The Gross Domestic Income (GDI) is the summation of the income from rent, salaries, profit, and interest, along with sales taxes, depreciation, and the net foreign factor income. While the GDP represents an expenditure approach to the measurement of economic output and growth, the GDI represents an income approach to the measurement of economic output and growth. However, according to the CEA, both measures are limited by the fact that while they are to be identical in theory, they tend to differ in practice as a result of measurement errors (CEA, 2015); hence, the suggestion of the Gross Domestic Output (GDO), which is the average of the GDP and the GDI.

\section{Theoretical Framework}

The classical theory remains the foremost known theory of money framed after Irvinng Fisher's Quantity Theory of Money (QTM), which verifies a relationship between money and economic indices. Irvinng regarded money and output as constant and that a rise in the volume of money causes a proportionate rise in price. Following Irvinng's proposition, Gali (2008), and Mankiw and Taylor (2007), reported the role of real factors on long term growth and money supply on short term neutrality. Keynes failed to consider the theoretical implications of the quantity theory and its applicability but however argued that the velocity of money was not stable and constant. QTM opines that the there is no tradeoff between output and inflation (Keynes, 1936). According to Keynesians, prices are rigid in nature while the money quantity adjust rather quickly. The demand for Money is endogenous and exogeniousity is based on indices including income and rates of interest as postulated by the theory of liquidity preference. Hicks (1937) explains that the theory explains a nexus between interest rate and output commonly known as the LM curve. The primary idea of the IS_LM model postulate a fixed price level; whose usage cannot be substantiated in the explanation of inflation except in output in the short run.

The liquidity preference theory considers the quantity of money demanded and supplied by the central bank to verify that level of equilibrium. At this equilibrium point, interest rate is the monetary indices. Money supply is considered to be an exogenous variable. An increase in the quantity of money supplied will cause a decrease in the interest rate at which the amount of money demanded is same with the supply. A reduced interest rate produces an improved capital and investment efficiency, hence; leads to expansion in output. Hicks IS/LM idea of the Keynes's theory was, nevertheless, examined empirically (Robinson, 1962; Leijonhufvud, 1968; Backhouse and Bateman, 2011). Keynes was skeptical on the effectiveness of monetary policy hence, accepted the role of the fiscal policy. The principles following the classical and Keynesian theory of money has been challenged by modern day theories (Romer, 2006). Distortions were said to be the outcome of sustained low interest rates in the Keynes theory. This level of interest rate gave rise to an unsustainable asset price bubbles (Schwartz, 2009).

Monetarist theory became known in the 1950s, with its principles formed from the QTM. It assumed as stable the velocity in the quantity theory of money implying that nominal income is greatly a function of the supply of money (Friedman and Schwartz, 1963; Friedman 1968, 1970). Monetarist supported the principle which in the trade-off between out and inflation but readjusted the Philips curve in real wage and nominal wage (Gottschalk, 2005). In the labour market, equilibrium is derived at an assumption of prevailing wages. The nominal wages and prices connotes that monetary policy influences real income in the short run; a surge in stock of money causes an increase in real output (GDP) temporarily 
and create employment in the short run. However, there are no effects in the long run. This is as a result of countervailing impacts including the surge in the price level. In the long run, money supply is inflationary, hence; the theory assumes neutrality in long-run monetary policy (Bernanke and Mihov, 1998; Bullard, 1999; Nogueira, 2009).

The New Classical Model and New Keynesian Model is a New Consensus Model; supporting the rationality of the classical model and retaining the Keynesian wage and price short run neutrality. It is a principle seeking to deal with inflation, with stability in price as the primary objective and growth as secondary. Interest rates are the only monetary instrument. This model presupposes that monetary instrument should focus on output stabilization in the short run and price stability in the long run. The output stabilization can be identified along the New Classical Model aggregate demand curve, where the output level varies inversely to the real interest rate. By implication, Fontana and Palacio-Vera, (2007) reported that this meant that short term monetary rates impact the demand side of the economy which in the long run, converges in the supply side equilibrium.

\section{Review of Empirical Studies}

Literature documents the impact of monetary policy on economic growth, with limited consensus till date. Most studies have reported no influence of the monetary policy. For instance, on a time series data spanning between 1997 to 2010, Mutuku and Koech (2014) used the VAR method to verify monetary and fiscal policy shocks on economic growth in Kenya. Result showed both money supply and short-term interest rates to be insignificant in influencing the real output. Weak structural, regulatory and institutional framework was responsible for the weak relationship.

Kamaan (2014) used the vector auto regressive (VAR) model to quantify the influence of monetary policy on Economic growth. For Kamaan, there was no impact on economic growth. This confirmed earlier findings by Montiel et al. (2012) who adopted the recursive and structural VAR to Monet report Monetary Transmission Mechanisms (MTMs) for Tanzania with data spanning 2002m1-2010m9. Lashkary and Kashani (2011) examined the impact of monetary instruments on Iran's economic growth between 1959 to 2008 using the regression model. The result established no significant nexus between the real economic variables, economic growth, employment and money volume.

Apparently, some studies also verify the positive relation of monetary policy on economic growth. Havi and Enu (2014) studied the role of fiscal and monetary policy on Ghana's economic growth from 1980 to 2012. The study used the Ordinary Least Squares (OLS). Result revealed that money supply as a measure monetary policy. Vinayagathasan (2013) confirms positive impact of monetary policy on Sri Lanka's real economy using seven-variable structural VAR model between 1978 and 2011. For the Nigerian economy, Kareem et al. (2013) used OLS method and correlation to confirm positive relationship of fiscal and monetary policies on real GDP growth between 1998 and 2008.

Using the Error Correction Model (ECM) on timeseries data for 1975 to 2010, Fasanya et al. (2013) studied monetary policy effect on economic growth of Nigeria. Result established a long-run nexus among the variables. External reserve, inflation rate and exchange rate were significant monetary policy variables that affected growth. Money supply was not significant. Onyeiwu (2012) used OLS between 1981 and 2008 to report the impact of monetary policy on the Nigerian economy. Result showed that monetary policy exerted a positive impact on GDP growth. Other studies with positive impact of monetary policy on economic growth include Al-Mashat et al. (2008) for South Asian countries; Rafiq and Mallick (2008) on output of Germany, France, and Italy; Khabo and Harmse (2005) for South Africa; Suleiman et al. (2009) for Pakistan; Moursi and El Mossallamy (2010) for Egypt and Senbet (2011) for USA. All studies followed the time series approach.

Literature also shows the lending and savings impact. For instance, Schoar (2009) documented the impact of lending activities in facilitating growth and competition. The author underscores the importance of capital from lending to the growth and expansion of an economy. Similarly, Agha et al. (2005) in a study of the transmission mechanism of monetary policy in Pakistan documented the impact of lending. It concluded that lending channels were means by which monetary policies gets to the real sector hence surge economic growth. Ibrahim and Ogunde (2013) examined the impact of Money Market on the economic growth of Nigeria. Deposit as a variable had a positive relationship with GDP but was not significant. This was because the deposit grew, ratio of loan also increased. Ibrahim and Ogunde (2013) also recorded a significant positive relationship between lending activities and economic growth.

\section{III.METHODOLOGY}

This study adopts a quantitative research approach. Previous studies on the subject, including Gali (2008) and Mankiw and Taylor (2007), had adopted the quantitative approach. The quantitative approach is ideal for this study because it involves time series data collection. Hence there is the need for estimation. This method assists in explaining facts, outcomes and numerically estimating the result. Descriptive and inferential statistical analysis are used in the analysis and evaluation.

Model

Following empirical literature, this study presents a model after Oni et al. (2012), Banton (2021), and Okoyan \& Peter (2021). It expresses a baseline regression model of economic growth as a function of monetary policy, market dynamics, savings and lending activities. Where the dependent variable is logged economic growth $\left(\mathrm{LGDP}_{\mathrm{t}}\right)$, the independent variables are monetary policy $\left(\mathrm{MPR}_{\mathrm{t}}\right)$, Savings 
Deposit Rate $\left(\mathrm{SADR}_{\mathrm{t}}\right)$ and Prime Lending Rate $\left(\mathrm{PRLR}_{\mathrm{t}}\right)$ and Treasury Bills Rate $\left(\mathrm{TBR}_{\mathrm{t}}\right)$

$\mathrm{LGDP}_{\mathrm{t}}=f\left(\mathrm{MPR}_{\mathrm{t}}, \mathrm{PRLR}_{\mathrm{t}}, \mathrm{SADR}_{\mathrm{t}} \mathrm{TBR}_{\mathrm{t}}\right) \quad(1)$, then written as:

$\mathrm{LGDP}_{\mathrm{t}}=\beta_{0}+\beta_{1} \mathrm{MPR}_{\mathrm{t}}+\beta_{2} \mathrm{PRLR}_{\mathrm{t}}+\beta_{3} \mathrm{SADR}_{\mathrm{t}}+\beta_{4} \mathrm{TBR}_{\mathrm{t}}+\mathrm{Ui}_{\mathrm{t}}$ (2)

\section{Sources of Data}

This study uses quarterly time series data with the sample period from 2010 to 2019 . The effect of four variables on Gross Domestic Product (GDP), which is used as an indicator of economic growth, is assessed. These variables are Monetary policy $\left(\mathrm{MPR}_{\mathrm{t}}\right)$, Savings Deposit Rate $\left(\mathrm{SADR}_{\mathrm{t}}\right)$ and Prime Lending Rate $\left(\mathrm{PRLR}_{\mathrm{t}}\right)$ and Treasury Bills Rate (TBRt). Treasury bills rate is used as proxy for Government lending activities. The data on all variables are sourced from the Central Bank of Nigeria (CBN)

\section{Estimation techniques}

The study estimates the parameters of the variables by way of descriptive statistics; mean, minimum, maximum etc. Secondly, it conducts a correlation analysis, which will help to determine whether or not there multicollinearity in the data being assessed. The study then estimates the Fully Modified Ordinary Least Square (FMOL) Regression to evaluate the research questions. FMOLS transformation asymptotically eliminates the endogeneity and cancels for asymptotic bias resulting from contemporaneous correlation between the regression and stochastic regressor's error.

\section{IV.RESULT \& DISCUSSION}

Table 2. Result of Descriptive Statistics

\begin{tabular}{|c|c|c|c|c|c|}
\hline & LGDP & MPR & PRLR & TBR & SADR \\
\hline Mean & 16.59154 & 11.81410 & 16.72077 & 9.703077 & 2.980256 \\
\hline Median & 16.59000 & 12.00000 & 16.76000 & 10.42000 & 3.380000 \\
\hline Maximum & 16.76000 & 14.00000 & 19.03000 & 14.49000 & 4.230000 \\
\hline Minimum & 16.35000 & 6.000000 & 14.92000 & 0.000000 & 1.400000 \\
\hline Std. Dev. & 0.104919 & 2.472692 & 0.772949 & 3.846196 & 1.052777 \\
\hline Skewness & -0.405214 & -1.349326 & 0.164700 & -1.154441 & -0.380648 \\
\hline $\begin{array}{c}\text { Kurtosis } \\
\text { Jarque- } \\
\text { Bera }\end{array}$ & 2.482655 & 3.658923 & 4.092245 & 3.736237 & 1.486963 \\
\hline $\begin{array}{c}\text { Observatio } \\
\text { ns }\end{array}$ & 39 & 39 & 39 & 39 & 39 \\
\hline
\end{tabular}

In the period under investigations, Monetary Policy Rate (MPR) a proxy of Monetary policy had mean value of $11.8 \%$. It had a minimum value of $6 \%$ and a maximum of $14 \%$ with a standard deviation of $2.4 \%$. The mean Treasure Bills Rate (TBR) which is used as proxy for market dynamics is $9.7 \%$ rising from $0 \%$ to about $14 \%$ and a standard deviation of $0.7 \%$ during the period under investigations. The mean Economic Growth proxied by Logged Gross Domestic
Product is 16.5 rising from 16.35 to 16.76 . Deposit Rate $\left(\mathrm{SADR}_{\mathrm{t}}\right)$ is used to represent deposit activities has a mean value of 2.9 , minimum value of $1.4 \%$ and a maximum of 4.2\%. Similarly, Prime Lending Rate (PRLRt ${ }_{\mathrm{t}}$ ) averaged $16.7 \%$ during the period. Its minimum is $1.4 \%$ while its maximum is $19.0 \%$. The value for the Kurtosis varies among variables. The lowest is 1.4 and the highest is 4.0. This indicates that the data set is leptokurtic. The distribution is normally distributed as indicated by Jarque-bera. The skewness which shows the asymmetry of the observation indicates a mix of negatively skewed and have a relative low value for the variables. The distribution is normally distributed as indicated by Jarque-bera.

Table 3. Result of Correlation

\begin{tabular}{|c|c|c|c|c|c|}
\hline & $L G D P$ & $T B R$ & $M P R$ & $S A D R$ & $P R L R$ \\
\hline LGDP & 1 & & & & \\
\hline TBR & -0.0860 & 1 & & & \\
\hline MPR & 0.7611 & 0.4478 & 1 & & \\
\hline SADR & 0.6926 & -0.0156 & 0.6908 & 1 & \\
\hline GOV & -0.1522 & -0.1283 & -0.0101 & 0.2226 & 1 \\
\hline
\end{tabular}

Table 3 shows the result of correlation analysis. The model of interest is model 1 where causality runs to Log of GDP. From the result, multicollinearity is absent since the coefficient of correlation among the independent variables are not high (up to 0.8 and above). Conclusively, the series lacks multicollinearity.

Capital market (which provide long term funds and is made up of Stock markets and Bond markets), Money markets, (which provide short term debt financing and investment), Derivatives markets, (which provide instruments for the management of financial risk), Futures markets, (which provide standardized forward contracts for trading products at some future date), Commodity markets, (which facilitate the trading of commodities), Insurance markets, (which facilitate the redistribution of various risks,), and Foreign exchange markets, (which facilitate the trading of foreign exchange).

Table 4. Result of FMOLS Regression Analysis

\begin{tabular}{|c|c|c|c|c|}
\hline Variable & Coefficient & Std. Error & t-Statistic & Prob. \\
\hline MPR & 0.021081 & 0.005451 & 3.867355 & 0.0005 \\
\hline PRLR & -0.020813 & 0.010475 & -1.986919 & 0.0553 \\
\hline SADR & 0.038593 & 0.011142 & 3.463678 & 0.0015 \\
\hline TBR & -0.045806 & 0.022295 & -2.529748 & 0.0164 \\
\hline C & 16.63709 & 0.171971 & 96.74361 & 0.0000 \\
\hline R-squared & 0.674673 & Mean dependent var & 16.59789 \\
\hline $\begin{array}{c}\text { Adjusted R- } \\
\text { squared }\end{array}$ & 0.635239 & \multicolumn{2}{|c|}{ S.D. dependent var } & 0.098424 \\
\hline S.E. of regression & 0.059444 & \multicolumn{2}{|c|}{ Sum squared resid } & 0.116608 \\
\hline $\begin{array}{c}\text { Long-run } \\
\text { variance }\end{array}$ & 0.001762 & & & \\
\hline
\end{tabular}

Dependent Variable: LGDP

Source: Authors computation using Eviews 
In the model above, the diagnostic test shows that estimates $R^{2}$ is 0.67 . This implies a good fit for the model. By implication, over $67 \%$ of the variations in economic development is caused by our independent variables. The beta values of the coefficient are as follows:

The impact of the monetary policy on the output level of the Nigerian economy

Monetary Policy (MPR) has a significant and positive impact on Economic Growth; $(b=0.021, \mathrm{t}=3.86, p<0.05)$. By implication, a rise in monetary policy rate by $1 \%$ improves economic growth by $2 \%$. The current study does not support earlier findings by Mutuku \& Koech (2014) and Kamaan (2014) who reported that MPR had no influence on economic growth but supports Havi \& Enu (2014) and Vinayagathasan (2013).

Dynamics in the money market and its influence on the growth of the Nigerian Economy

Treasury Bills Rate (TBR) is used as proxy for dynamics in the money market. It has a significant and negative influence on Economic Growth $(b=-0.045, \mathrm{t}=-2.52$, $p<0.05)$. By implication, if money market dynamics increases by $1 \%$, economic growth falls by $4.5 \%$. The current study fails to support previous studies who documented that dynamics in the money market was responsible for economic growth (Oni et al., 2012; Econlib, 2019).

Deposit and lending activities of the money market and Influence on the Economic growth

Saving Deposit Rate (SADR) is used as proxy for saving activities. It has a significant and positive impact on Economic Growth; $(b=0.038, \mathrm{t}=3.463, p<0.05)$. By implication, if deposit activities increase by $1 \%$ economic growth increases by $3.8 \%$. Prime Lending Rate (PRLR) is used as proxy for Lending activities. It has a significant and negative relationship with Economic Growth $(b=-0.020, \mathrm{t}=-$ $1.986, p<0.05)$. By implication, if lending activities increase by virtue of a $1 \%$ decrease in lendig rate, economic growth rises by $2 \%$. The result supports previous studies by Schoar (2009) who documented the impact of lending activities in facilitating growth and competition. Similarly, it validates the study by Agha et al. (2005) who identified lending as medium of expansion. It also supports Ibrahim and Ogunde (2013) who found positive relationship between lending and deposit activities with economic growth.

\section{CONCLUSION \& RECOMMENDATION}

There is no doubt that the growth of the economy of a nation constitutes one of the paramount aspirations of its stakeholders, particularly the government, investors, institutions, policy makers, and the population at large. The Monetary policies is one instrument with enormous implication for growth. This study examined the impact of the monetary policy, influence of dynamics in the money market as well as the influence of deposit and lending activities of the money market on the growth of the Nigerian economy. Preliminary analysis shows evidence of long run equilibrium relationship which implies that the variables exhibit a common deterministic trend. The regression result, shows that monetary Policy (with MPR as its proxy) has a significant and positive impact on Economic Growth. For Government lending activities and its influence on the growth of the Nigerian Economy, result shows a significant and negative influence on Economic Growth. Finally, Deposit activities (SADR) has a significant and positive impact on Economic Growth. While lending rate has a significant and negative influence on Economic Growth, the inverse relationship between lending rate and lending activities (given that higher lending rate results in lower lending activities and vice versa) suggests a positive relationship between lending activities and economic growth. On the whole, the results of the impact of monetary policy on economic growth in Nigeria depicts the nature of the financial structure, characterized by a low level of development. Monetary policy and market dynamics and deposit activities impact the economy positively. Therefore, the study recommends that measures to further promote monetary policy, market dynamics, as well as deposit and lending activities be put in place to promote economic growth.

\section{REFERENCES}

[1]. Adam, Mustafa. (2009). Financial markets: The recent experience of a developing economy. Savings and Development. 33. 27-40.

[2]. Adambekova, A., \& Andekina, R. (2013). Financial Market and its Definitions: Transformation of Scientific Concepts. World Applied Sciences Journal, 27(12-16).

[3]. Agha, A.I., Ahmed, N. Mubarak, Y. A. \& Shah. H (2005). Transmission Mechanism of Monetary Policy in Pakistan SBP Research Bulletin.

[4]. Al-Mashat, R., \& Billmeier, A. (2008). The monetary transmission mechanism in Egypt (Working Paper No. 07/285). International Monetary Fund. Retrieved from https://www.imf.org/ external/pubs/ft/wp/2007/wp07285.pdf

[5]. Backhouse, R. E. and D. E. W. Laidler (2011). What Was Lost with IS-LM? History of Political Economy 36 (annual suppl.), The IS-LM Model: Its Rise, Fall, and Strange Persistence, ed. K. ${ }^{\circ} \mathrm{D}$ Hoover and M. De Vroey, pp. 25-56.

[6]. Banton, C. (2021). Market Dynamics. Investopedia. Retrieved 6 September 2021, from https://www.investopedia.com/terms/m/market-dynamics.asp.

[7]. Bernanke, B.S and Mihov, I. 1998. Measuring monetary policy. The quarterly journal of economics, Vol. 113, No.3, (August).

[8]. Bullard, J. (1999). Testing long-run neutrality propositions: Lessons from the recent research. Federal Reserve Bank of St. Louis Review, Vol. 81, No.6, pp. 57-78.

[9]. CEA. (2015). A Better Measure of Economic Growth: Gross Domestic Output (GDO). Washington: Council of Economic Advisers. Retrieved from https://obamawhitehouse.archives.gov/sites/default/files/docs/gdo_ issue brief final.pdf

[10]. Cœuré, B. (2012). The importance of money markets. Speech, Tourrettes, Provence.

[11]. Cornwall, J. (2018). Economic growth. Encyclopedia Britannica. Retrieved 6 September 2021, from https://www.britannica.com/topic/economic-growth.

[12]. Darškuviené, V. (2010). Financial Markets. Education and Culture DG.

[13]. Econlib. (2019). Economic Growth. Econlib. Retrieved 6 September 2021, from 
https://www.econlib.org/library/Topics/College/economicgrowth.h tml.

[14]. Fasanya, I.O. and Onakoya, A.B.O. (2013) Does Monetary Policy Influence Economic Growth in Nigeria? Asian Economic and Financial Review, 3, 635-646

[15]. Firebaugh, G., \& Beck, F. (1994). Does Economic Growth Benefit the Masses? Growth, Dependence, and Welfare in the Third World. American Sociological Review, 59(5), 631. https://doi.org/10.2307/2096441

[16]. Fontana G. and A. Palacio-Vera (2007). Are long-run price stability and short-run output stabilisation all that monetary policy can aim for? Metroeconomica, Vol. 58, No.2, pp. 269-298

[17]. Friedman, M and Schwartz, A. (1963). Money and business cycles. Review of Economics and Statistics, pp.32-64.

[18]. Friedman, M and Schwartz, A. (1970). Monetary Statistics of the United States: Estimates, Sources,Methods. Columbia University Press for the NBER, New York.

[19]. Friedman, M. (1968). The role of monetary policy, American Economic Review, Vol. 58, No.1, pp. 1-17.

[20]. Gali, J. (2008). Monetary policy, inflation and business cycle: An introduction to the New Keynesian Framework. Oxfordshire: Princeton University Press.

[21]. Goodfriend, M. (2011). Money Markets. Annual Review Of Financial Economics, 3(1), 119-137. https://doi.org/10.1146/annurev-financial-102710-144853

[22]. Gottschalk, J. (2005). Monetary Policy and German Unemployment Problem in Macroeconomic Models: Theory and Evidence. Berlin German, Springer-Verlag Berlin Heidelberg.

[23]. Hartmann, P., Heider, F., Papaioannou, E., \& Duca, M. (2007). The Role of Financial Markets and Innovation in Productivity and Growth in Europe. Frankfurt: European Central Bank.

[24]. Haruna, I. (2019). Financial Markets and Monetary Policy: A Review of Issues, Theories, Methodology and the Way Forward. SSRN Electronic Journal. https://doi.org/10.2139/ssrn.3327382

[25]. Havi, E. D. K., \& Enu, P. (2014). The effect of fiscal policy and monetary policy on Ghana's economic growth: Which policy is more potent? International Journal of Empirical Finance, 3(2), 6175.

[26]. Hicks, J.R. (1937) Mr. Keynes and the "Classics": A Suggested Interpretation. Econometrica, $\quad$ 5, 159.https://doi.org/10.2307/1907242

[27]. Ibrahim Sublim, Ogunde O., Shaheed B,(2013). Impact of Money Market Operations On the Economic Growth Of Nigeria (1981 2013)

[28]. Ivic, M. (2015). Economic Growth and Development. Journal Of Process Management - New Technologies, 3(1), pp. 55-61.

[29]. John, I., Oluyemisi, O., \& Bashir, S. (2021). The Impact of Money Market Operations On the Economic Growth of Nigeria (1981 2013). African Scholar Publication, 3. Retrieved 6 September 2021.

[30]. Kamaan, C, K. (2014). The effect of monetary policy on economic growth in Kenya. International Journal of Business and commerce, Vol 3, No.8, (April).

[31]. Kareem, R. O., Afolabi, A. J., Raheem,K. A., \& Bashir, N. O. (2013). Analysis of fiscal and monetary policies on economic growth: Evidence from Nigerian democracy. Current Research Journal of Economic Theory, 5(1), 11-19. Retrieved from http://www. maxwellsci.com/print/crjet/v5-11-19.pdf

[32]. Keynes, J.M. (1936) The General Theory of Employment, Interest, and Money. John Maynard Keynes

[33]. Khabo, V. and Harmse, C. (2005). The impact of monetary policy on economic growth of a small open economy: the case of South Africa. South African Journal of Economic and Management Sciences, 8(3), pp. 84-102.

[34]. Kizito, E. (2012). The Place of Financial Markets in the Development Process: Evidence from Nigeria. Journal of Economics And Behavioral Studies, 4(11), 649-659. https://doi.org/10.22610/jebs.v4i11.365

[35]. Lashkary, M., \& Kashani, H. B. (2011). The impact of monetary variables on economic growth in Iran: A Monetarists' Approach. World Applied Sciences Journal, 15(3), 449-456. Retrieved from https:// pdfs.semanticscholar.org/ec51/5675d6573c4405a 5e858976275cf433b867f.pdf

[36]. Leijonhufvud, A. (1968). On Post Keynesian Economics and the Economics of Keynes. New York: Oxford University Press.

[37]. Machado, M., Ceretta, P., \& Costa, A. (2015). Economic Development and Economic Variables. Encontro Nacional De Engenharia De Producao.

[38]. Mankiw, G.N. and Taylor, M.P. (2007). Macroeconomics. (European Edition ed.) Basingstoke: Palgrave Macmillan.

[39]. Monteil, P., Adam, C., \& O'Conell, S. (2012). Financial architecture and the monetary transmission mechanism in Tanzania (Working Paper No 03). Centre for the Study of African Economies. Retrieved from http://www.csae.ox.ac.uk/materials/ papers/csae-wps-2012-3.pdf

[40]. Moursi, T, A. and El Mossallamy, M. (2010). Monetary policy analysis with New Keynesian Models for Egypt. Information and Decision Support Center (IDSC) of the Egyptian Cabinet Working paper

[41]. Mutuku, C., \& Koech, E. (2014). Monetary and fiscal policy shocks and economic growth in Kenya: VAR econometric approach. Journal of World Economic Research, 3(6), 95-108

[42]. Nogueira, R. P. (2009). Is monetary policy really neutral in the long-run? Evidence for some emerging and developed economies. Economics Bulletin, Vol 29, No. 3, pp. 2432- 2437

[43]. Nwankwo, G.O., (2001). Money Market: Problems and Prospects. Unp: 9-29

[44]. Odunga, R., \& Ayoyi, I. (2021). Impact of Financial Markets On the Economic Growth of East Africa. European Journal Of Logistics, Purchasing And Supply Chain Management, 4(5), 25-33.

[45]. Okoyan, K., \& Peter, E. (2021). Effect of Money Market Instruments On Capital Market Performance in Nigeria. European Journal Of Accounting, Auditing And Finance Research, 9(2), 6780.

[46]. Oni, A., Emoh, F., \& Ijasan, K. (2012). The Impact of Money Market Indicators on Real Estate Finance in Nigeria. Sri Lankan Journal Of Real Estate, (6), 16-37.

[47]. Onyeiwu, C. (2012). Monetary policy and economic growth of Nigeria. Journal of Economics and Sustainable Development, 3(7), 62-70. Retrieved from http://www.iiste.org/Journals/index.php/JEDS/ article/viewFile/2046/2025

[48]. Prajapati, D. (2014). Money Market and Secondary Market. International Journal For Research In Management And Pharmacy, 3(8), 20-24.

[49]. Rafiq, S. M. and Mallick, K.S. (2008). The effect of monetary policy on output in EMU3. A sign restriction approach. Journal of Macroeconomics, Vol. 30, pp. 1756-1791

[50]. Robinson, J. 1962. Review of Johnson (1962). Economic Journal, 72(1), 690-2

[51]. Romer, D. 2006. Advanced Macroeconomics. (3rd Ed. ed.). New York: McGraw-Hill/Irwin.

[52]. Schoar, A. (2009)Lin Roundtable: Scale Matters. Free Exchange, Economist.com blog Available.

[53]. Schwartz, A. J. (2009). Origin of the financial market crisis of 2008. In P. Booth (Ed.), Verdict on the Crash: Causes and Policy Implications, pp. 45-50. London: The Institute of Economic Affairs.

[54]. Stosic-Mihajlovic, L. (2016). Functioning of financial and capital markets in modern conditions. Journal Of Process Management. New Technologies, 4(4), 30-38.

[55]. Stosic-Mihajlovic, L. (2016). Functioning of financial and capital markets in modern conditions. Journal Of Process Management. New Technologies, 4(4), 30-38.

[56]. Suleiman, D. Wasti, S. Lal, I and Adnan, H (2009). An empirical investigation between Money supply, Government expenditure, output and prices; The Pakistan Evidence. European Journal of Economics Finance and Administrative science, 17, pp. 60-68.

[57]. Vinayagathasan, T. (2013). Monetary policy and the real economy: A structural VAR approach for Sri Lanka (Discussion Paper No. 13-13). National Graduate Institute for Policy Studies. Retrieved 
from http://www.grips.ac.jp/r-center/wp-content/ uploads/1313.pdf

[58]. Violeta, G. (2010). Introduction to the foreign exchange market. Journal of Knowledge Management, Economics and Information Technology, 1(1), 1-14.

[59]. World Bank. (2021). GDP growth (annual \%) - Nigeria | Data. Data.worldbank.org. Retrieved 6 September 2021, from https://data.worldbank.org/indicator/NY.GDP.MKTP.KD.ZG?end $=2019 \&$ locations=NG\&start=1999.

\section{Appendix}

Appendix 1. Result of the Ordinary Least Squares

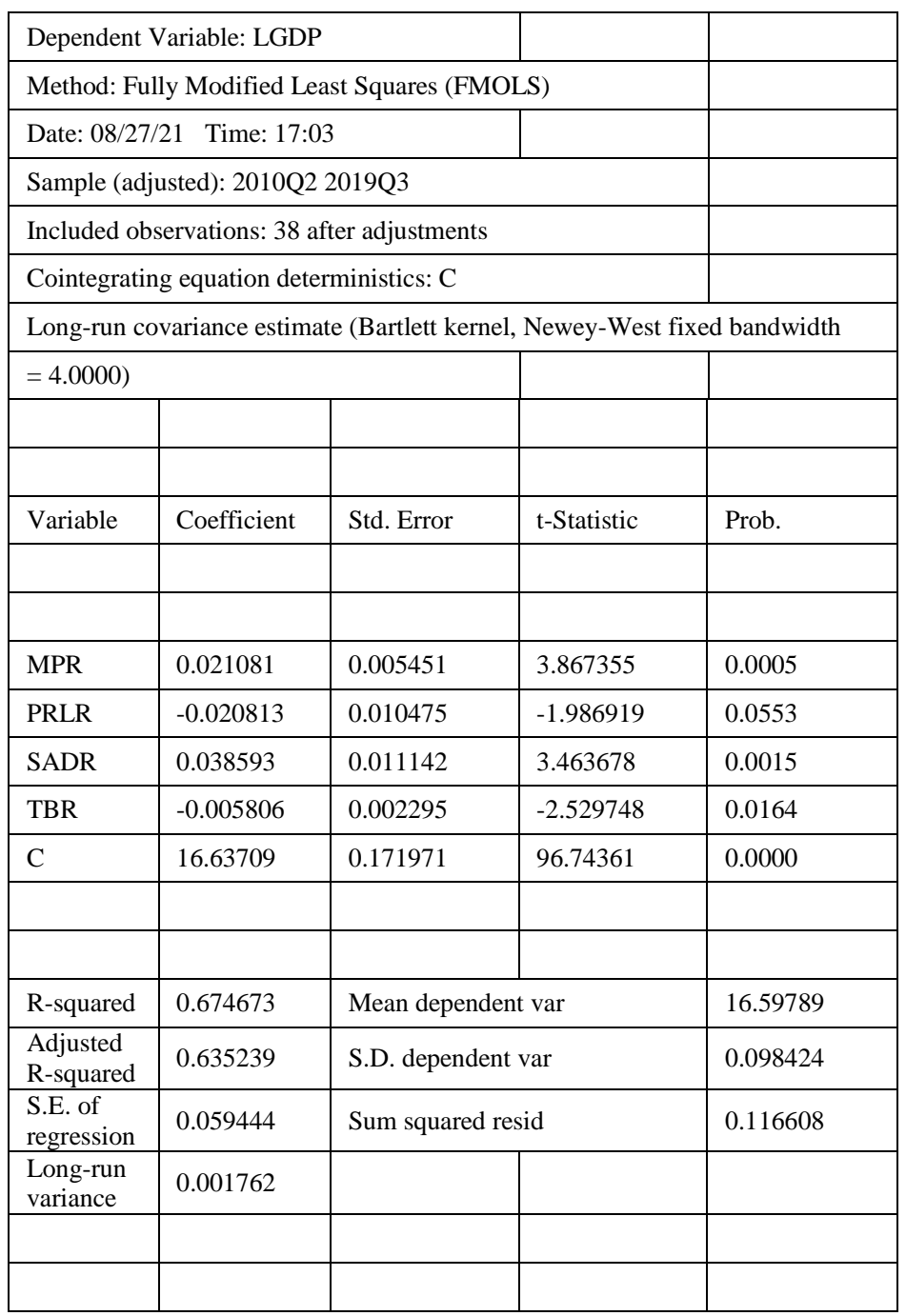


Appendix 2. Result of Descriptive Statistics

\begin{tabular}{|c|c|c|c|c|c|}
\hline & LGDP & MPR & PRLR & TBR & SADR \\
\hline Mean & 16.59154 & 11.81410 & 16.72077 & 9.703077 & 2.980256 \\
\hline Median & 16.59000 & 12.00000 & 16.76000 & 10.42000 & 3.380000 \\
\hline Maximum & 16.76000 & 14.00000 & 19.03000 & 14.49000 & 4.230000 \\
\hline Minimum & 16.35000 & 6.000000 & 14.92000 & 0.000000 & 1.400000 \\
\hline Std. Dev. & 0.104919 & 2.472692 & 0.772949 & 3.846196 & 1.052777 \\
\hline Skewness & -0.405214 & -1.349326 & 0.164700 & -1.154441 & -0.380648 \\
\hline Kurtosis & 2.482655 & 3.658923 & 4.092245 & 3.736237 & 1.486963 \\
\hline Jarque-Bera & 1.502213 & 12.53997 & 2.114945 & 9.543592 & 4.661885 \\
\hline Probability & 0.471844 & 0.001892 & 0.347333 & 0.008465 & 0.097204 \\
\hline Sum & 647.0700 & 460.7500 & 652.1100 & 378.4200 & 116.2300 \\
\hline Sum Sq. Dev. & 0.418308 & 232.3397 & 22.70308 & 562.1426 & 42.11690 \\
\hline Observations & 39 & 39 & 39 & 39 & 39 \\
\hline
\end{tabular}

